\title{
Landscapes and national imagination: The role of national parks in the formation of national belonging in Turkey
}

\author{
Asya Ece Uzmay ${ }^{1,1}$ \\ ${ }^{1}$ Kadir Has University, Faculty of Art and Design, Department of Architecture, Istanbul, Turkey
}

\begin{abstract}
When the concept of a national park idea was first established in the USA, it was promoted as the ownership of the landscape for the use of the people while emphasizing national identity through nature. As a latecomer to this movement, this paper describes part of the journey of the establishment of national parks in Turkey, with a focus on the period between 1950 and 1975. In this paper I argue that the national parks were a means of constructing a national identity through the transformative power of modernism on the countryside. Focusing on different national parks from Turkey, I interrogated the role of these so-called pristine and primitive lands in the construction of national identity through different forms. Under the threat of neoliberal economic policies and new approaches to understanding of nature these protected and reserved pieces of "nature" deserve more attention.
\end{abstract}

\section{Introduction}

National Parks were originally defined by the US Congress as "a great breathing-place for the national lungs" [1] (quoted by [2]). It was 1883 and there was an ongoing debate on whether Yellowstone should be declared a national park or not. National parks include the "preservation of the nature" idea which can be found within Modernism as well as having a role in the formation of national identity - stunning dramatic scenery defining the unique character of the USA. In this paper I interrogate this relationship between the landscape and the national identity within the scope of Turkey by discussing how national identity is built through nature, especially in the case of national parks which tame and rationalise nature through a modernisation process.

The national park idea defines a landscape preserved for a nation protected from the developmental ideas of modernism and modernisation. To Henry David Thoreau, one of the late $19^{\text {th }}$ century Transcendentalist intellectuals in America who was influenced mostly by English and German Romanticism, wilderness is seen "as a

\footnotetext{
${ }^{1}$ Corresponding author: a.eceuzmay@gmail.com
} 
reservoir of intellectual nourishment for civilized men" [2: 102]. The historian Simon Schama mentions "the Father of the National Parks" John Muir's declaration on the impossibility of pureness: "in order to keep it pure we have to occupy it" (quoted in [3: 9]). The human interpretation of wilderness resulted in the manipulation of nature and the displacements of the native people who inhabited it along with a utilitarian approach to its management.

I question the national park idea by drawing on scholarship, mainly from Denis Cosgrove's idea of landscape as a source for rootedness, belonging, and identity [4] and James C. Scott's idea of controlling the landscape in nation-building [5] as well as William Cronon's questioning of constructed nature [6]. First, I look for the national park as an idea of preserving pristine lands for the benefit of a nation as it emerged in the United States and spread through the world. Then, I briefly examine the history of the national park idea in Turkey with a focus on the turning points in the perception of the national parks and sacredness of the landscape. Following this, I look at the preservation idea, imported by the United States Agency for International Development $\left(\mathrm{USAID}^{2}\right.$ to Matossian's delayed-developed ${ }^{3}$ countries, as a norm of civilized people in the case of Turkey.

\section{The national park idea: The dichotomy of domesticity and wilderness}

In the modernist discourse, landscape has a major role in nation-building. Claiming a piece of land as the origin of the nation strengthens the idea of a nation rooted in a specific space or land. That piece of land might be either a place already in existence or a totally imagined one, such as Turan for the Turkish people, or the German Drang nach Osten myth, or the Gaelic tribal culture for Irish people as their birth place [8]. Mythical landscapes, such as Turan, claim the idea of the nation's origin as belonging to a particular geography. The cyclic feature of time in nature, and the power of recreation after death, feed the idea that the nation will last for all eternity, as a "consolation for our mortality" [3: 15].

Before nation states, there were city-states in which citizens could communicate with their immediate community within their immediate surroundings. Landscapes were a part of their practical knowledge, just like in village life. However, after the advent of the territorial nation-states it became a duty for citizens to become familiar with every part of their land. Therefore, landscape went beyond practical knowledge and served other purposes. These lands were studied systematically and in detail in order to emphasize and claim the idea of belongingness. Geography started to be a subject taught in schools. It became the duty for every citizen to memorize the geography of their land to strengthen the idea of collectively belonging in an imagined community in a certain land ${ }^{4}$.

The 'primitive' lands within the borders of states were enigmatic objects, which could be dominated by producing descriptive knowledge. Domination over nature can be seen in relation with the colonial discourse of Napoleonic excursions. Producing the knowledge of "untouched" places corresponded with claiming power over the lands.

\footnotetext{
${ }^{2}$ USAID is still working for National Parks around the world. In 2009, they established the first National Park of Afghanistan [7].

${ }^{3} \mathrm{I}$ am borrowing the concept from Mary Matossian.

${ }^{4}$ For a discussion on geographic education in modern states as an example from Turkey, see [9] and [10].
} 
This also resembles the idea of the separation of colonial thought: the dominator (man) and dominated (nature, wilderness) pacts. With its inhabitants, nature is seen as wilderness and a place waiting for discovery and examination. The idea of having control over nature, a utilitarian approach and a taming idea can be seen through building dams, cultivating fields and deforestation or afforestation, slaughtering bison and regulating nature [5].

In 1872, the Yellowstone became the first national park in the world. With a distance of "enlightened men" from "nature" and the relentless spread of the built environment, debates on "the protection of wilderness" started to rise. This resulted in the idea of protecting the American Wilderness as examples of divine architecture, as sources of moral prestige alongside technological development, as mentioning the civilized human presence on primitive wilderness. Besides, the idea of preserving these lands was seen as a "nourishment" of enlightened man [2]. In the process of nation-building in America, there were supposed to be differences from a European identity. As Coates and Beinart mention: "Americans located their ancient and hallowed relics not in crown jewels and gothic cathedrals but in redwoods and 'purple mountain majesties' " [11: 75]. Also for Hammond, the march of civilization has crossed a continent. For "making the old wilderness blossom as a rose" and "progressive influence" there should "not only [be] miracles like locomotives, the telegraph, and photography but 'moral prestige' as well" [2: 104]. However, later on, these claims were supported by the economic values of the lands through the utilitarian approach, which were contradictory to the definition of nature preservation.

Conversely, "wilderness" stands as an ambiguous concept since what is defined as wilderness represents the boundaries of civilized man. After Yellowstone was declared a national reserve, the government forced the Native Americans to move off the land. This situation ignores the previous inhabitants and projects power relations on wilderness $^{5}$. Instead of displacement, displaying the human habitat of the wilderness can also be a way of preservation. For example, in Grand Canyon National Park, the Hopi people and their performances, staged as daily entertainment became part of the wilderness experience for tourist consumption [12]. It was a complete performance of nature for its timelessness. As the National Park idea expanded across the country to increase the representation of "American Wilderness" and for the needs of urbanite visitors who wanted to have the experience of nature without any surprises, the National Park Service adopted standardized rules for the duration of visits, such as the general behaviour towards living and non-living objects [2]. Also, by building roads, viewpoints, in-park education facilities, safety precautions and planned travel routes there emerged a predictable form of visit to these wild-but-tamed landscapes.

\section{National parks in Turkey: exhibiting the greatness of the homeland}

In Turkey, the first regulation regarding national parks was enacted in 1956, as part of the "Forest Law". According to the law, forestry areas that have distinct features should be protected for scientific research, recreational and touristic purposes for the sake of the nation [13]. However, the idea of establishing a national park in Turkey goes further than this with writings on the notion of protecting nature via national parks. In particular, the Uludağ Mountain had a major influence on the national park concept. Just before

\footnotetext{
${ }^{5}$ We see similar enforcements in Turkey, too. For example, in Olympus Seashore National Park plan, the former village in the beach were planned to relocate in somewhere else to "protect" the wilderness within the proper conditions.
} 
the Forest Law was enacted in 1956, an article was published in the architecture magazine Arkitekt about the ongoing debate on the national park idea. This article was supported with images and maps of national parks from the United States along with an explanation of the national park concept. Then it argued the ambiguous situation of Uludağ and whether it should have a national park status [14]. The debates on 'emphasizing' Uludağ go back to the 1930s and had been discussed in the media. Thus, applying regulations to nature for recreational purposes became a topic of public debate and paved the way for the Forest Law.

\section{Conquering the mountain: Uludağ National Park}

Uludağ became a national park in 1961, yet the debates surrounding it have a longer history. Long before it was conquered by the Ottomans, it was known as "Keşiştepe (Peak of the Monk)" and Mount Olympus. It was a sacred place for Christians, one that was home to monasteries. It earned the name "Uludağ" (means "Sublime Mountain") after Osman Şevki Uludağ, a deputy of Konya, who was influenced by the "greatness" of the mountain. He said, "This mountain [Uludağ] is the highest peak and has a dominant view of Anatolia. This part of Anatolia suffered a lot from the counterdiscourses of the monks over the centuries. Turks were oppressed here" [15]. By changing the name, he declared the sovereignty of Turks both over the land and the mountain; both over Christianity and nature.

This nationalist narrative was quite common. In 1932 an article was published in the Cumhuriyet Newspaper, declaring the conquest of the mountain as conquering a "Christian" mountain for Turks and a daunting object of nature by taming it.

We could not yet find a proper way to benefit from the magnificent piece of nature. Although this enormous piece of work was so close, almost no one knew and examined it thoroughly. Thanks to Fatin Bey, the Governor of Bursa, a road had been built in a spot very close to its peak, with a hotel built in a dominant position on the mountain.

He stated:

It was known as 'Keşiş (Monk)' in old geography books, however now its name has been changed to 'Uludağ', this late seral forest has been opened to men, these deserted and wild peaks have been tamed. Now, this winding road which passes within the dense pine trees as a white strip, demonstrates that even this terrifying mountain can be tamed by man [16].

After Uludağ became accessible, it started to be viewed in the media as a place for performing sports, especially for skiing. In 1933, Bursa Mountain Sports Club was established "to improve mountain sports and to spread this sport which also serves for the defence of the motherland, throughout the country" [15]. The mountain was "conquered" with accommodation places, phone line and roads. It was in the service of the children of the nation as a triumph for the Republican idea [17].

Additionally, in the writings of Selahattin Inal, one of the professors of the Department of Forestry in İstanbul University, we can see a resemblance to Cosgroves's idea of landscape. Inal relates that along the "tree ornamented" road to Uludağ, the trees are like the strong men who protect the land. He also sees them as an allegory of the re-birth of the nation. He continues by praising how Turks claimed the territories from Byzantium. Along the same road, the children of the nation would feel the greatness and the beauty of the homeland and be proud. Besides this, he pictures Uludağ with the small village houses dotting its skirts, and wants to see them all in white 
as "pearls that will shine in the early sun and support the beauty of Uludağ" [18]. As Urry mentions, landscapes and cities are inadequate without a framed and detached perspective [19]. To give joy to its spectators -which are the children of this nation- the view should be tamed.

\section{USAID Period}

At first, natural and recreational potential were important factors for a place to be considered as a candidate for a national park. Indeed, the National Park Department was under the Ministry of Forests. They usually worked together with the Ministry of Tourism and Information and Ministry of Reconstruction and Resettlement. Although there were attempts in the parliament to build more institutionalized regulations for national parks, the National Park Law took 25 years before it came into effect. With the Second Five Year Development Plan (1968-1972), in 1967, the State Planning Organization and USAID worked together in establishing national parks in Turkey. Zekai Bayer was the project coordinator as Head of the National Park Department in Turkey and had a key role in this collaboration. After completing forestry studies at Istanbul University, following Marshall Aid, he found several opportunities to visit the United States, the founder of the national park idea. In the United States, he studied recreational planning of forested areas and tourism.

The collaboration between USAID and the State Planning Organization lasted for four years. During this period, a team of architects, an archaeologist, an engineer and a planner from the USAID together with the architects, technicians, forestry engineers and archaeologists from Turkey worked on twelve different projects and prepared the "Long Term Development Plans". It was a transition to a more systematic way of building up the knowledge of these pristine nature areas. They studied factors such as the average daily sunny period, relative humidity, monthly precipitation averages with data reaching back to 1926, the historical background and importance of the places with their general approach to the site. The plan was worked in detail and varied according to the features of the area. For example, in the Master Plan for Protection and Use of Halicarnassus Seashore National Park it is written that "this plan recognizes the need to protect outstanding examples of the cultural and scenic heritage of Turkey for the education and enjoyment of her own people as well as international visitors" [20].

Then it continues with an emphasis on the unique natural features and socioeconomic facilities. Also, keeping with a non-traditional model, they say that they are also protecting the ongoing human adaptation into a natural coastal landscape as an important socio-economic factor. These kinds of variety are attractive for tourists [20]. The aim was to preserve these coasts as an open air museum with all the local people, habitats and nature in it regardless of time, both as a reminder of pre-historic times and the primitive nature of early humankind. While they aimed to display the adaptive possibilities of humankind into nature through transformative power, in the Kovada Lake National Park, situated in Isparta, the claim was to give a sense of "familiarity". In the project, dating back to 1970 , it was declared that the information centre was positioned at the entrance of the park to remind the visitors that they are entering a controlled "wilderness". By design, the sense of alienation should be lowered and the feeling of acquaintance supported with accommodation areas in order to provide the comfort of "home" and an organization of the beach area [21].

Conversely, in Köprülü Kanyon, USAID defined the place as "one of the nation's prime outdoor recreation resources," with planning to promote a successful outdoor experience with viewpoints and photo stops alongside sport activities. Thus, the 
experience of a tourist was to be embodied within the park not only as a spectator of the nature but also as a performer within this "challenging" national land [22].

Architectural themes within the parks were another topic in the designs of USAID. For instance, in Olympus National Park, near Antalya, it was emphasized that the area should not be affected by "modernity". The architecture should have features such as "modern use of traditional materials and basic colours in simple forms and "the human scale of a regional architectural style must be consistent throughout the development. There will be no attempt to copy the traditional or classic architectural motifs or to mock natural forms" [23]. In Bergama National Park, which consists of the archaeological ruins of ancient Pergamon City, the architecture should not suppress the monumentality of the ancient city. "Conscientious design can create this contrast through the use of plain surfaces, light structures, open spaces, human scale". Again there is an emphasis on functional design to avoid "mocking the motifs of the historic structures or imitating the forms or textures of nature. Simplicity will be the keynote." Rather than being part of the landscape these buildings should be distinctively separate from nature and the ruins, yet they should be inviting in their "self-sufficient" and human-scaled designs, avoiding an impression of monumentality [24].

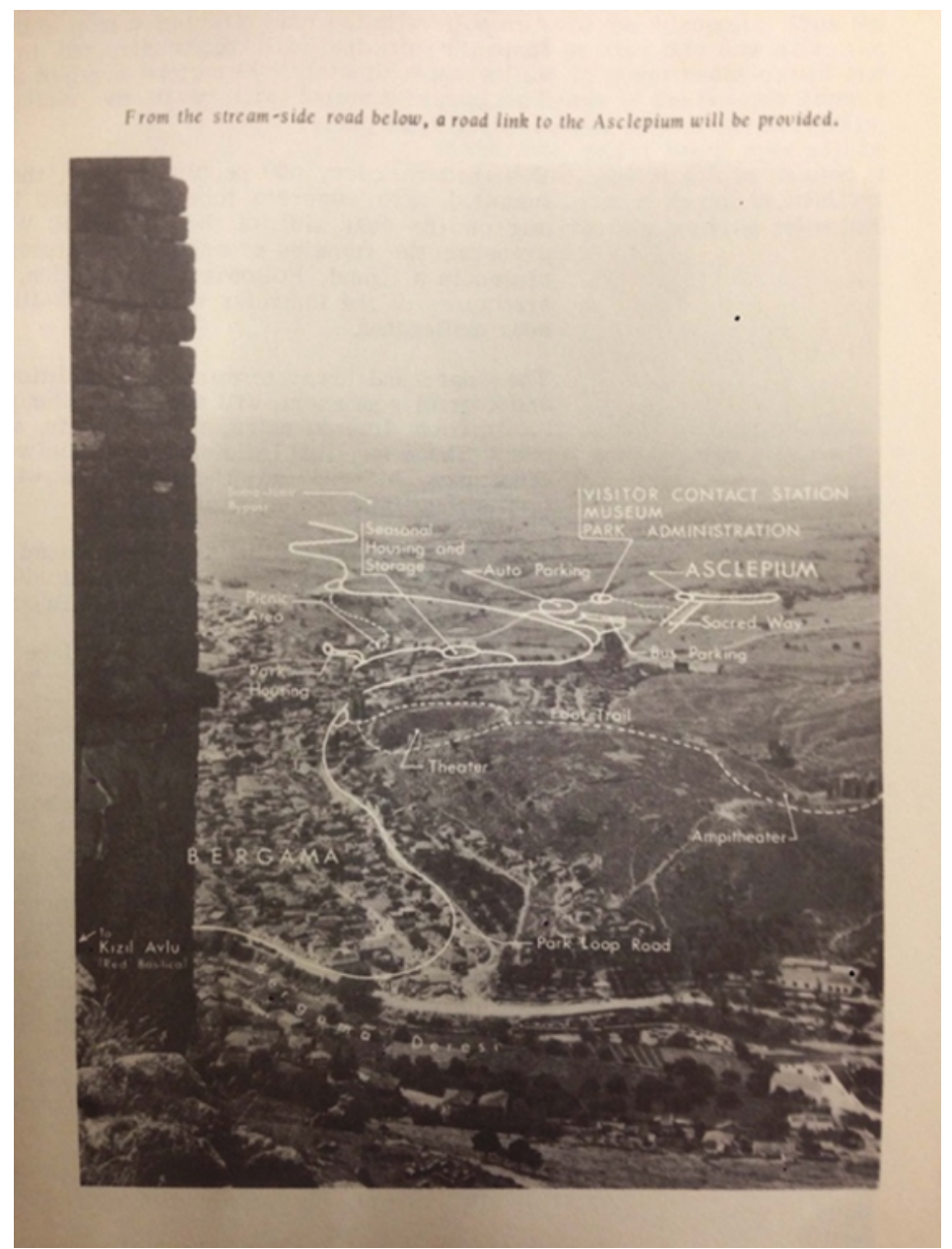

Fig. 1. Aerial view of the Bergama National Park Master Plan [24]. 
As for Köprülü Kanyon National Park near Antalya, the "architectural theme should recall the native building style in a modern vernacular. Masonry walls, large porches, and sheltering roofs found in the village house are appropriate features for park structures" [22]. In the history of architecture, modernity is always detached from tradition and the vernacular by emphasizing that the vernacular idea is also unstable and also part of a political discourse. The vernacular can be seen as the primitive phase of architecture in relation to the place and its defined identity. That use of "modern vernacular" from a team of US and Turkish experts is important to emphasize here.

\section{Conclusion}

In Uludağ National Park, taming the landscape through modernist features and declaring victory over nature were the dominant discourses while in USAID projects, the national park idea and the modernization project were strongly related with the local and vernacular ideals. In these examples we see different forms of modernization discourses through the countryside.

In the American national park idea, these lands were defined as democratic territories and as a home for the nation [25: 9]. Even though they promoted the idea as a democratic landscape for everyone and drew a picture of "home" which underlines the terms of belonging and identity, in practice it produces a dichotomy of inclusions and exclusions by accessibility in preserved areas. The national park was promoted as "America's Best Idea"6 with the emphasis on "you". The citizens of America, whoever they are, own those landscapes. This mode of thinking allows for setting roots on a more democratic ground. In Turkey there has been some resizing of the boundaries of national parks and disruption to the unity of the lands by construction projects. The national park idea is not only about protection of common grounds, but also a way of reading into the policies and philosophies of the sovereign state. Once they were a part of nationalist writing; now they are threatened by the government which is emphasizing nationalism in different ways. As an example from the AKP government, establishing new national parks while destroying others can exist at the same time ${ }^{7}$. With the law of 2014, the protective features of national parks have been threatened and the former idea of protection has been lost under the push for development. Infrastructure projects have started to be seen as a part of pristine lands ${ }^{8}$. However, these topics should be discussed in another arena where the agency of nature and non-human actors are in focus, while rivers, mountains and elements of natures can earn the same legal rights as humans [26].

\section{Acknowledgements}

This paper forms part of a master class called "Trans-National Histories of Modern Architecture and Urbanism" by Professor Sibel Bozdoğan in the Architecture and Urban Studies Master Programme at Kadir Has University. Therefore, I would like to thank my professor for encouraging

\footnotetext{
${ }^{6}$ It is a movie about National Parks in America, produced in 2009 by Ken Burns.

${ }^{7}$ If we follow the latest National Parks that established in the AKP era, there is a focus on former war areas as an emphasis on national history. Like the Battle of Sakarya National Park (2015), the Battle of Malazgirt Historical National Park (2018). So, the protection reasons of the national parks can be another paper topic.

${ }^{8} \mathrm{~A}$ highway within the boundaries of Gallipolu National Park has been built.
} 
me to write about this topic. I would also like to thank to Murat Tülek, Berra Zeynep Dodurka and Charles Ali Wagner for their precious contributions to this paper.

\section{Brief Resume}

Asya Ece Uzmay is an architect who graduated from İstanbul Technical University in 2016. She continues her studies in Architecture and Urban Studies Master Programme at Kadir Has University, İstanbul. She is currently working as a research assistant in the department of architecture in the same university. Her recent research explores the water and the water infrastructures in İstanbul with a focus on the social, political and historical aspects.

\section{References}

1. VEST, G.G. (MO) 1883. "Sundry Civil Appropriation Bill", Congressional Record (47 ${ }^{\text {th }}$ Congress, $2^{\text {nd }}$ session), vol. 14/3: 3488. Retrieved from: https://archive.org/details/congressionalrec47eunit/page/n744 [available on January 10 2019].

2. NASH, R. F. (1967) 2014. Wilderness and the American Mind, Yale University Press.

3. SCHAMA, S. 1995. Landscape and memory, New York, Vintage Books.

4. COSGROVE, D. E. 1998. Social formation and symbolic landscape. Madison, (WI), University of Wisconsin Press.

5. SCOTT, J. C. 1998. Seeing like a state: How certain schemes to improve the human condition have failed, Yale University Press.

6. CRONON, W. (ed.) 1996. Uncommon ground: Rethinking the Human Place in Nature, New York, W.W. Norton and Company.

7. USAID PRESS OFFICE, 2009. USAID Helps Establish First National Park in Afghanistan [Press release], April 23. Retrieved from https://www.usaid.gov/news-information/press-releases/usaid-helps-establishfirst-national-park-afghanistan [available on 2 January 2018].

8. SMITH, A. D. 1986. The Ethnic Origins of Nations, Oxford, Cambridge, Blackwell.

9. ÖZKAN, B. 2012. From the Abode of Islam to the Turkish Vatan: The Making of a National Homeland in Turkey, New Haven (CT), Yale University Press.

10. KEZER, Z. 2011. "Memleketi Tahayyül Edebilmek: Erken Cumhuriyet Döneminde Milli Eğitimin Maddi Kültürü" [Envisioning a Hometown: The Material Culture of National Education in the Early Republican Period], in Dosya, $\mathrm{n}^{\circ}$ 27: 79-87.

11. COATES, P.; BEINART, W. 1995. Environment and History: The Taming of Nature in the USA and South Africa (Historical Connections), London - New York, Routledge. DOI: https://doi.org/10.4324/9780203133552

12. BONNEMAISON, S.; MACY, C. 2003. Architecture and Nature: Creating the American Landscape. Routledge.

DOI: https://doi.org/10.4324/9780203402030

13. TBMM. 1956. Orman Kanunu [Forest Law], 3078. 
14. Birleşik Amerika'da Milli Parklar [National Parks in the United States] (1953). Arkitekt, $\mathrm{n}^{\circ}$ 259-260: 97-102.

15. BURSA KENT KONSEYI [The City Council of Bursa], 2013. Gazete Sayfalarında Bir Zamanlar Uludağ [Once upon a time Uludağ, in the newspapers].

16. Cumhuriyet Newspaper (1932).

17. Cumhuriyet Newspaper (1936).

18. INAL, S. 1945. Yeşil Bursa Denizinde İnci Uludağ [Green Bursa Sea Inci Uludag]. Hüsnü Tabiat Matbaası.

19. URRY, J.; LARSEN, J. 2011. The Tourist Gaze 3.0. London, SAGE Publications.

20. NATIONAL PARK PLANNING TEAM, 1971. Halicarnassus Seashore National Park: Master Plan for Protection and Use. Ankara, USAID/T.

21. NATIONAL PARK PLANNING TEAM, 1972. Kovada Lake National Park: Master Plan for Protection and Use. Ankara, USAID/T.

22. NATIONAL PARK PLANNING TEAM, 1971. Köprülü Canyon National Park: Master Plan for Protection and Use. Ankara, USAID/T.

23. NATIONAL PARK PLANNING TEAM, 1971. Olympus Seashore National Park: Master Plan for Protection and Use. Ankara, USAID/T.

24. NATIONAL PARK PLANNING TEAM, 1970. Pergamum Historical National Park: Master Plan for Protection and Use. Ankara, USAID/T.

25. GREBOWICZ, M. 2015. The National Park to Come. Stanford (CA), Stanford University Press.

26. ROY, E.A. 2017. "New Zealand Gives Mount Taranaki Same Legal Rights as a Person", The Guardian (22 ${ }^{\text {nd }}$ December). Retrieved from:

https://www.theguardian.com/world/2017/dec/22/new-zealand-gives-mounttaranaki-same-legal-rights-as-a-person [available on 13 January 2018]. 